\title{
Value-Semantic Attitude to Bribery as a Form of Grass- Roots Corruption Among Working Adults
}

\author{
Dzhaneryan Svetlana Tigranovna ${ }^{1}$ and Gvozdeva Darya Ivanovna ${ }^{1, *}$
}

\author{
${ }^{1}$ Southern Federal University, Rostov-on-Don, 344000, Russia \\ *Corresponding author. Email: darya-gvozdeva@yandex.ru
}

\begin{abstract}
The destructive nature of the corruption effect and the ultra-tolerant attitude of the citizens towards the grassroots of corruption has been a focus for many types of research and became a basis for this study. The study is aiming to establish the types of value-semantic attitude to bribery as a form of grass-roots corruption and originality of its components found among 216 working professionals in South of the Russian Federation. Survey (a questionnaire to assess the meaning of each component of the attitude towards bribery), analysis of the open questions in the questionnaire, testing and statistical methods are used in the work. The research considers such an attitude as a value-semantic purposeful attitude where bribery is presented as a substitution of certain needs, goals, and values. The study reveals the cognitive, emotionally evaluated, and conative components of the attitude. Based on the dominant verbal-semantic version of bribery (its subjective interpretation and functional purposes identified by the working professionals) the research designates the following types of value-semantic attitude to it: "Business economic transaction", "Instrumental value", and "Illegal act". The specific content of each component of this attitude is revealed for working professionals, depending on the type of attitude towards bribery.

Keywords: bribery as a form of grass-roots corruption, value-semantic attitude, types and components of
\end{abstract}

attitude, adult working subjects

\section{INTRODUCTION}

Awareness by the global community of the universal and systemic nature of corruption is supported by indications of its political $[17 ; 29]$, legislative $[15 ; 20 ; 39,5]$, socioeconomic $[29 ; 38]$, historical $[1 ; 15,21]$, ethnocultural $[24 ; 35 ; 36]$, organizational $[19 ; 22]$, religious [35], psychological $[2 ; 3 ; 8 ; 11 ; 21 ; 23 ; 25 ; 35]$ grounds correlated with the fixed index of corruption perception.

Manifestations of corruption have various representative types and forms. This fact is considered by researchers as one of the differentiating factors of its perception and people's attitude to it $[15 ; 39]$. The research interest is focused primarily on top-level corruption, while the most common is grass-roots corruption, which is, as a rule, committed by officials at the lower and middle levels of the service ladder [39]. One of the most common forms of corruption is bribery, which is disclosed as a voluntary offer, promise, giving, receiving, or accepting a bribe (material values - items, money, services, or other property benefits) in order to influence the actions of an official in their favor [39]. Bribery is considered as receipt by the bribe-taker (bribed official), giving by the bribe-giver (engaged in bribery) of a bribe with possible participation of a mediator [9]. This form of corruption is well-known and practiced by citizens; it is directly related to the shadow economy, and is regarded by its participants as mutually beneficial. It causes less significant monetary damage to the state than top-level corruption. Over-tolerant attitude of citizens to grass-roots corruption (especially in the areas of law, health, education), its routine character, scale, daily reproducibility $[11 ; 12 ; 25 ; 32 ; 30 ; 39]$ nullify anti-corruption measures aimed at ensuring even minimal acceptable results in this social situation. Destructive nature of the corruption effects, the emphasis of modern researchers in various branches of science given to psychological aspects of corruption mechanisms $[15 ; 21$; $25 ; 35 ; 36 ; 38 ; 39]$, the interest of the public and specialists in the development of targeted programs on anti-corruption education make it relevant to monitor constantly the content of psychological attitude of citizens to corruption. The tasks of psychological analysis of corruption and anticorruption education correspond to the potential of the integral category "attitude", the theoretical and methodological basis for the study of which is the concept of psychological attitude [37] and our own ideas about value-semantic attitude of an individual [31]. Psychological attitudes, being an integral system of individual, selective, conscious connections of an individual with various aspects of reality, flow from the entire history of a person's development, express their personal experience and constitute their actions and experiences [37]. Interpretation of a psychological attitude as a conscious, arbitrary, individualized, conative one, which also contains a personal meaning or value for the 
subject of objective side, allows us to study the content and structure of the attitude to corruption.

Analysis of research works into attitudes to corruption has led to a number of conclusions. Often "attitude" is used terminologically as an auxiliary, obvious concept for generalizing results of sociological surveys $[18 ; 24 ; 28$; $35]$. However, the results of these surveys show noncoincidence of a wide range of respondents' interpretations of bribery with its legal interpretation, a possibility of typologization of the attitude and specific features of the content of each of its components.

The key issue in the study of this attitude is its content, reflected in the prototypes of forms of corruption presented and evaluated by the respondent. Solution to this question is complicated by discussions about scientific definitions of corruption manifestations [5;7]; methodological tradition of studying perception of corruption through assessment of its severity in test tasks presented to a respondent; lack of clarity for citizens and social undesirability of specific types and forms of corruption. This confirms reasonability of studying the attitude to bribery as a form of corruption. Attitudes to corruption are directly or indirectly meaningfully denoted or even typified by the criteria of "tolerance" [8;18;28;30;35], "ethics" [28; 29], "utility, instrumentality" [25: 30], and its objective side is endowed with the meaning of an acceptable and convenient mechanism for social life and solving personal problems [25], a forced response to objective circumstances [8], and a specific value $[27 ; 30]$. These positions indicate relevance of studying the attitude in the context of significance of its objective side (bribery) to meet the needs of a subject, of consideration of psychological attitude to bribery as a value-semantic attitude, and of possibility of its typologization by the criterion of sense load of bribery. In the value-semantic attitude to bribery, its objective side acts as endowed with a fixed meaning for a subject and is presented in their mind as a representation of its meaning (place, role, functional purpose) for achieving goals of the subject. In other words, the valuesemantic attitude to bribery is purposeful, in which bribery is comprehended as a tool in achieving goals of a subject and meeting their needs. The three-component structure of the attitude [37] involves disclosure of the content of each of its components - cognitive, emotional-evaluative and conative. The meaning of bribery (its interpretation and functional purpose) is presented in the content of the cognitive component of this attitude. The cognitive component is crucial for the designation and subsequent analysis of the value-semantic attitude to bribery.

Emotions towards bribery among ordinary citizens are recorded in a wide range of feelings which vary in modality and sign: indifference, apathy [8: 15], negative experiences $[4 ; 6 ; 10]$, forced acceptance [15], positive emotions from participation in corrupt transactions [4]. We emphasize connection between modality of emotions and such variables as the stage of getting used to corrupt behavior [27], the status of corrupt officials [8; 15], their role in corruption transactions [12], and prevention of corruption $[4 ; 21]$. With this in mind, we considered the content of the emotional evaluation component as including not only emotions about bribery, but also assessments of its consequences and prevention.

The conative component of the attitude is expressed in motives and resulting affirmations, readiness to act in one way or another with an object [37]. For the attitude to bribery, the content of its conative component can be attributed to the widely studied causes [20], situational factors [26], and justification [28; 35] of corruption manifestations. We have included the factors and the justification for giving and receiving a bribe in the content of the conative component. At the same time, we proceeded from the social and legal undesirability of bribery, as well as from the specifics of the attitude to corruption.

A number of studies report inconsistencies and incoherencies in the attitude to corruption, and the lack of a direct link between each of its components. The specific feature of the attitude to corruption is such that the majority of citizens' knowledge of corruption and its destructive consequences $[6 ; 10 ; 16]$, as well as condemning corrupt officials and designation of strict preventive measures against them $[1 ; 3 ; 6 ; 8 ; 10 ; 15 ; 16]$, are combined with initiation, support, and ignorance of citizens' own corrupt practices [15, 16, 3] its application for more effective solutions to everyday problems [6], justification of their own corrupt behavior by the situation, compulsion (pressure of social stereotypes), which significantly reduces subjective perception of risk and guilt [3]. All of these indicate expediency of studying attitude to bribery.

The content of each of the components of the holistic attitude significantly depends on the role and functional purpose of corruption (in particular, bribery) in meeting certain needs of a subject (the bribe giver or the bribe taker) in different spheres of life $[8 ; 16 ; 30 ; 32]$. Bribery for a subject performs a service role in satisfying their own needs. The verbal version of the meaning of bribery is presented by a subject in interpretation of bribery and its functional purpose (the cognitive component of the attitude).

Based on these regularities we considered the attitude to bribery being a form of corruption as a value-semantic purposeful attitude, in which bribery is presented in the mind of a subject as a substitution of a means (goal, value) in implementation of their certain needs [31]. This attitude is three-component in structure, including cognitive (interpretation and function of bribery in representation of a subject), emotional and evaluative (emotions about bribery; assessment of its impact on the state, social groups, and an individual; prevention), and conative (factors of giving and receiving a bribe, justification of giving and receiving a bribe) components.

As a result of our previous research, we have revealed features of types of value-semantic attitude to bribery among urban youth in the South of the Russian Federation - high school students, university students, young (under 30 years old) working subjects [31; 33; 34]. However, psychological practice needs empirically verified knowledge about the features of this attitude also in adult subjects who are actively involved in transformative activities, propagate their existing attitudes, including those 
to bribery, in education, mentoring, and leadership of younger people. All this makes it relevant to establish the types of value-semantic attitude to bribery as a form of grass-roots corruption, the content originality of their components among adults (31-55 years old) working people. In the future, it is planned to identify patterns of dynamics of the types of this attitude, psychological characteristics of its subjects, and develop individualized strategies for anti-corruption education of citizens.

\section{PURPOSE, SUBJECT, AND SAMPLE OF THE STUDY}

The purpose of the study: to establish types of valuesemantic attitude to bribery and reveal originality of the content of their components among working adult subjects. The subject of the study: the content of the components of the value-semantic attitude to bribery; the object - the attitude to bribery among working adult subjects.

Empirical object of research: 216 male and female adults (aged between 31 and 59 years) employed in various types of professions in the South of Russia.

\section{PROBLEMS AND METHODOLOGY}

Methodically, the content of attitudes to bribery in most studies is recorded as a result of direct surveys $[13 ; 14 ; 18$; 28; 35]; statements on psychological portraits of corrupt officials given by respondents [11]; assessment of corruption potential of presented cases [14]; selfassessment of corruption potential in behavioral intentions [10]. In some cases, content analysis of open questions in the questionnaire aimed at identifying attitudes to corruption is used [4]. We share the view that it is necessary to increase methodological base of the study, focusing on actual, individual cases of corruption, including contextual factors, unforeseen situational circumstances, various areas of behavior and activity of people $[4 ; 13 ; 14]$, while relying on direct, a priori not set opinions and assessments of specific respondents.

The research methods were: a survey (an author's questionnaire that allows you to evaluate the content of each of the components of the attitude to bribery), content analysis of open questions in the questionnaire, testing (the scale of differential emotions by K. Izard); methods of parametric and nonparametric statistics.

Primary data processing included content analysis of open questionnaire questions aimed at determining the content of the components of the attitude to bribery. Pilot coding of respondents' responses, expert assessment ( 3 psychological experts with at least 5 years of experience) of the adequacy of the choice of category indicators (each expert's assessment on the 10-point scale of the indicator according to its adequacy to the corresponding category); determination of the measure of consistency of these assessments (based on pairwise Spearman's rank correlation coefficients $(r=,>0.7 ; p<0.05)$; set between the values of expert assessments of the area of indicators in a particular category). As a result, indicators were accepted with the average expert rating of or greater than 6 points, and correlation coefficients, as a measure of consistency of expert assessments, were equal to or more than 0.7. Further, the relative frequency of occurrence of the category was calculated, each of which reflected the content of the cognitive, emotional-evaluative and conative components of the attitude to bribery $[31 ; 33 ; 34]$.

Content-semantic interpretations of bribery by respondents: an economic transaction ("receiving money or valuable gifts for a service, action", "providing a service for money"); an illegal act ("crime", "fraud", "bribing an official"); a universal means of meeting individual needs of subjects ("a simple way out of the situation", "a way to satisfy their whims).

Functions of a bribe: a resource function as saving time and personal resources ("speeding up the process", "making life easier"); an instrumental function of a bribe in solving everyday problems, including spheres of career and legal relations ("You can't achieve anything in Russia without it", "promoting an idea or business"); a destructive function ("otherwise you will be torn", "I suffer myself"); an economic function ("earnings", "additional income").

General, specific and individual consequences of a bribe were considered as effects of its influence on the state, social groups, and an individual. According to respondents, the consequences for the country affect the economy ("instability of the economy", "damage to the economy"), activities of the government and the state apparatus ("reduced efficiency of the state apparatus", "officials violate the law"), ideology and law ("ideology is deteriorating", "double standard of behavior"). For social groups, the consequences of bribery were seen as a decrease in professionalism ("fake doctors", "people in management are stupid"); destruction of inter-and intragroup social interaction ("growth of social tension", "unfair competition"); economic effects ("material damage"). As consequences of bribery for an individual respondents noted formation of socially undesirable personal traits ("inability to rely on their own knowledge", "loss of moral guidance"); specific social consciousness ("disillusionment with the state", "disbelief in the state as a tool for fair solution of problems") and legal awareness ("awareness that you are violating the law", "vulnerability to crime"); economic effects ("deprivation of money", "change in lifestyle due to financial problems"); positive results for a person ("the ability to achieve certain success in some areas", "possibility of entering a university"). When identifying the general, special, and individual consequences of bribery, respondents resorted to a uniquely negative assessment, which amounted to the category "negative effect".

Among preventive measures, respondents referred to stricter criminal penalties ("tighten the legal framework", "the death penalty"), administrative control ("video surveillance of employees", "dismissal"), increased wages ("adequate salaries"), political reforms ("drive corrupt officials out of power", "global purge"), anti-corruption education ("development and instilling appropriate 
priorities in people", "promotion of understanding the importance of honest work", "do not give or take bribes"), social control of citizens ("remuneration for denunciations when providing evidence of cases of bribes", "control and surveillance of the execution of punishments by citizens"). Factors of giving a bribe in the view of respondents: compulsion as a result of social pressure ("extortion", "hopelessness"); personal traits of subjects ("low social intelligence"), economic interest ("desire to get more money through certain frauds"), life situations in different areas of life ("settle problems with the law", "for good medical care", "getting a job", "achieve loyalty").

Factors of receiving a bribe in the opinion of respondents: compulsion "that who is higher in position, requires an interest"); personal traits of subjects ("greed"); economic interest ("desire to make easy money"); demonstration of power ("sense of superiority in their field of activity"); altruism, as assistance in solving problems in the areas of law, career, life management ("help arrange a place in a kindergarten", “driving school”, "providing a position”).

The following factors justify bribes, according to respondents: the situation, i.e., health problems occurring in a person's life ("health", "bribe for a doctor- always welcome!", "the man's life depends on it"), family ("for the sake of family members", "when the situation connected with children"), rights ("in a case of litigation", "petty breach of law"); effectiveness of a bribe as a guarantee of getting the desired result quickly ("for quick solutions to their problems", "the desired result"); being forced as a result of social pressure, stereotypes, traditions, etc. ("was forced", "no other way"). In a few cases, factors such as personality traits ("indecision") and gratitude ("gift") were reported, which were grouped into the "Other factors" category.

According to respondents, the following factors justify receiving a bribe: compulsion ("the boss forced"), economic interest ("you need to pay for services, nothing in life happens just for nothing"), personal traits ("it is the devil's work", "for the sake of moral satisfaction"); altruism as helping people ("fast providing of individual services", "helping a person").

Absence of answers to individual questions in the questionnaire was encoded by the "no answer" category, for which the relative frequency of occurrence was calculated, which was considered in the subsequent statistical analysis of the final results. Establishing emotional assessments of bribery (questionnaire question: What did you experience when faced with the fact of receiving or giving a bribe to someone?) was performed using a scale of differential emotions (K. Izard).

Statistical processing of the results was carried out on the basis of factor analysis, descriptive statistics, quartiling procedure, methods of nonparametric statistics: Friedman's, Wilcoxon's criteria, Spearman's rank correlation coefficient, binomial criterion. Statistical analysis was performed in the modules of Factor Analysis, Multiple Regression, Descriptive Statistics (Shapiro-Wilks' W-test) of the 'Tibco statistica 13.3' software program.
Factor analysis (main component method) was performed for values of relative frequency of occurrence in the categories (provided that the distribution of these values does not differ from the normal distribution) denoting definitions and functions of bribery. In this case, we proceeded from our views of the meaning of bribery, the interpretation and functionality of which is represented in the content of the cognitive component of the attitude, and of the critical importance of the cognitive component for labeling and subsequent analysis of value-semantic attitude to bribery.

A 3-factor solution was obtained for the entire response collection (Table 1), explaining $73.6 \%$ of the variance.

Table 1. Content and values of factor weights of interpretations and functions of bribery

\begin{tabular}{|l|l|l|l|}
\hline $\begin{array}{l}\text { Interpretations and } \\
\text { functions of bribery }\end{array}$ & $\begin{array}{l}\text { Factor } \\
\mathbf{1}\end{array}$ & $\begin{array}{l}\text { Factor } \\
\mathbf{2}\end{array}$ & $\begin{array}{l}\text { Factor } \\
\mathbf{3}\end{array}$ \\
\hline Resource function & 0.092 & -0.865 & 0.159 \\
\hline Instrumental function & 0.120 & 0.854 & 0.066 \\
\hline Illegal act & -0.815 & 0.021 & 0.554 \\
\hline No answer & -0.081 & 0.079 & -0.932 \\
\hline Economic transaction & 0.927 & 0.033 & 0.324 \\
\hline Universal means & -0.032 & -0.175 & -0.181 \\
\hline
\end{tabular}

Based on the meaningful analysis of the leading definitions and functions of bribery with a positive factor load $>0.5$, the types of attitudes were identified.

Type 1 (Factor 1) - "Business economic transaction" (34.7\% of respondents), here bribery is understood as social interaction, exchange of services and remuneration for it.

Type 2 (Factor 2) - "Instrumental value" (35.6\% of respondents), here bribery is understood as a universal means of satisfying various deficit needs of a person

Type 3 (Factor 3 ) - "Illegal act" (29.6\% of respondents), here bribery is considered from the point of view of its illegality, approaching its legal definition.

Hereinafter, the individual factor assessment was calculated, according to the high value of which (quartiling procedure, binomial criterion) groups of respondents with dominance of the corresponding ratio were identified. Further, in each of the groups of respondents demonstrating a particular type of attitude, the leading content of each of the components of the attitude was analyzed (Friedman's, Wilcoxon's criteria, $\mathrm{p}>0.05$ ). To establish the relation between the leading experience towards bribery and its prevention the values of positive correlation coefficients were determined (Spearman, $r=$; $\mathrm{p}<0.01)$.

\section{RESULTS AND DISCUSSION}

We reveal the content of components (Tables, 2, 3, 4) from the attitude types. The leading content of the cognitive component of attitude to bribery is given in Table 2 . 
Table 2. Content of the cognitive component of the respondents' attitude to bribery

\begin{tabular}{|l|l|l|}
\hline Type of attitude & Leading interpretation of bribery & Leading function of bribery \\
\hline Business economic transaction & Economic transaction & Resource \\
\hline Instrumental value & A universal tool to meet individual needs & Instrumental \\
\hline & Illegal act & $\begin{array}{l}\text { Resource } \\
\text { Instrumental } \\
\text { Economic }\end{array}$ \\
\hline
\end{tabular}

As it follows from Table 2, there is a specific content of the cognitive component of each attitude, which is dictated, first of all, by the logics of empirical establishment of the attitude types. However, this specificity is also evident in the content and scope of ideas about the functional purpose of bribery. Speaking about the attitude as "Business economic transaction" and "Instrumental value", respondents focus on a specific function of bribery resource and instrumental functions, respectively. In case of the "Illegal act" attitude, respondents characterize bribery in a multi-functional way, giving it resource, instrumental and economic functions.

The leading content of the emotional and evaluative component of attitude to bribery is given in Table 3 .

Table 3. Content of the emotional and evaluative component of the respondents' attitude to bribery

\begin{tabular}{|c|c|c|c|c|c|}
\hline \multirow{2}{*}{$\begin{array}{c}\text { Attitude } \\
\text { type* }\end{array}$} & State & Social group & Individual & Emotions & Preventive measures \\
\cline { 2 - 5 } 1 & $\begin{array}{c}\text { Economy } \\
\text { Negative effect }\end{array}$ & $\begin{array}{c}\text { Destruction of } \\
\text { interactions } \\
\text { Negative effect }\end{array}$ & Variability & Disgust & Interest \\
\hline 2 & $\begin{array}{c}\text { Economy } \\
\text { Negative effect }\end{array}$ & No answer & Personality traits & $\begin{array}{c}\text { Disgust } \\
\text { Interest }\end{array}$ & Criminal penalty \\
\hline 3 & $\begin{array}{c}\text { Economy } \\
\text { Negative effect } \\
\text { Activities } \\
\text { of authorities }\end{array}$ & Variability & $\begin{array}{c}\text { Personality traits } \\
\text { Economic effect } \\
\text { Negative effect }\end{array}$ & $\begin{array}{c}\text { Disgust } \\
\text { Surprise } \\
\text { Interest }\end{array}$ & Criminal penalty \\
\hline
\end{tabular}

*Notes: 1 - Business economic transaction, 2 -Instrumental value, 3 - Illegal act.

According to the results, along with the similarity of the content of the emotional and evaluative component of the attitude (the consequences of bribery for the state - the general negative effect and the negative effect on the country's economy; the expression of emotions - disgust, interest; prevention - the tightening of criminal penalties), there are differences due to the type of attitude. Respondents with the "Illegal act" attitude, in comparison to respondents with the "Business economic transaction" and "Instrumental value" attitude, are unanimously aware of a wider range of general, special and individual consequences of bribery, as well as emotional experiences about bribery.

Similarity of the leading emotions and preventions reflects, in our opinion, the established social stereotype of bribery: increased interest along with disgust (rejection) to it; strict legal measures of prevention. Taking it into account, we turned to the analysis of positive relationships between the leading emotional assessments (experiences) of bribery and its prevention (Table 4).

Table 4. Values of positive correlation coefficients between leading emotions about bribery and its prevention ( $\mathrm{r}=$; $\mathrm{p}<0.01)$

\begin{tabular}{|l|l|l|l|}
\hline \multirow{2}{*}{ Emotions } & \multicolumn{2}{|c|}{ Attitude type } & \multicolumn{2}{|c|}{ Illegal act } \\
\cline { 2 - 4 } & $\begin{array}{l}\text { Business } \\
\text { transaction }\end{array}$ & economic & Instrumental value \\
Interest & $\begin{array}{l}\text { Social control }(\mathrm{r}=0.293, \\
\mathrm{p}<0.01)\end{array}$ & $\begin{array}{l}\text { Political reforms }(\mathrm{r}=0.312 ; \\
\mathrm{p}<0.0056) \\
\text { Criminal penalty }(\mathrm{r}=0.239 ; \\
\mathrm{p}<0.036)\end{array}$ & $\begin{array}{l}\text { Administrative control } \\
(\mathrm{r}=0.36 ; \mathrm{p}<0.006)\end{array}$ \\
\hline Disgust & $\begin{array}{l}\text { Social control }(\mathrm{r}=0.413, \\
\mathrm{p}<0.00023)\end{array}$ & $\begin{array}{l}\text { Social control } \\
(\mathrm{r}=0.276 ; \mathrm{p}<0,015)\end{array}$ & Not determined* \\
\hline Surprise & None* & None* & Not determined* \\
\hline
\end{tabular}

Respondents with the "Business economic transaction" attitude, if they have a high interest in and rejection of bribery, prefer high social control as prevention; respondents with the "Instrumental value" attitude prefer political reforms, stricter criminal penalties, and social control. Respondents with the "Illegal act" attitude, if there is an increased interest in bribery, prefer administrative control as its prevention. 
As a result of studying the content of the conative component for each type of attitude, the similarity of the factors of giving and receiving a bribe was established. Situationality is the leading factor in giving a bribe, while economic interest is the priority for receiving it. Along with this, respondents who show the "Illegal act" attitude to bribery also note compulsion as one of the leading factors in giving a bribe, and respondents who show the "Instrumental value" attitude to bribery - demonstration of power as one of the leading factors in receiving a bribe (Table 5).

Table 5. Content of the conative component of respondents' attitude to bribery, including willingness to give and receive bribes

\begin{tabular}{|c|c|c|c|c|}
\hline $\begin{array}{c}\text { Attitude } \\
\text { type* }\end{array}$ & Factor of bribery giving & $\begin{array}{c}\text { Factor of bribery } \\
\text { receiving }\end{array}$ & $\begin{array}{c}\text { Justification of giving a } \\
\text { bribe }\end{array}$ & $\begin{array}{c}\text { Justification of } \\
\text { receiving a bribe }\end{array}$ \\
\hline 1 & Situationality & Economic interest & $\begin{array}{c}\text { Forced necessity } \\
\text { Effective-ness }\end{array}$ & $\begin{array}{c}\text { Economic interest } \\
\text { Altruism }\end{array}$ \\
\hline 2 & Situationality & $\begin{array}{c}\text { Economic interest } \\
\text { Demonstration of power }\end{array}$ & Not determined & $\begin{array}{c}\text { Forced necessity } \\
\text { Altruism } \\
\text { Economic interest }\end{array}$ \\
\hline 3 & $\begin{array}{c}\text { Situationality } \\
\text { Forced necessity }\end{array}$ & Economic interest & $\begin{array}{c}\text { Situationality } \\
\text { Forced necessity } \\
\text { Effectiveness }\end{array}$ & Forced necessity \\
\hline
\end{tabular}

*Notes: 1 - Business economic transaction, 2 -Instrumental value, 3 - Illegal act.

Basically, the general content of the emotional-evaluative and conative components of each type of attitude to bribery is socially stereotypical: bribery is negative for the state, and in particular, for its economy; it causes people's disgust and interest. Giving a bribe is motivated by the life situation, and receiving it is motivated by economic interest. Tougher criminal penalties are the leading prevention of bribery.

At the same time, the specificity of the content of each of the components of the attitude to bribery is clearly traced, depending on the type of this attitude.

If there is the "Business economic transaction" attitude, respondents attribute a resource function to bribery and note its negative impact on social groups, which is expressed in the destruction of social interaction. It is justified by performance and compulsion for the bribegiver, and by economic interest and altruism for the bribetaker. Having expressed interest or disgust at bribery, respondents see its leading prevention in the social control of citizens.

If there is the "Instrumental value" attitude, respondents attribute an instrumental function to bribery and note its negative impact on a person's personality traits. It is justified by variable factors for the bribe-giver and economic interest, altruism and compulsion for the bribetaker. Having expressed interest in or disgust to bribery, respondents refer to its prevention as social control of citizens, political reforms, and tougher criminal penalties. In the presence of the "Illegal act" attitude, respondents attribute instrumental, resource and economic functions to bribery; they note its negative impact on the activities of the government, its variable impact on social groups, and its negative impact on personal traits and economic well being of a person. It is justified by its effectiveness, the necessity or life situation for the bribe-giver and the necessity for the bribe-taker. If there is a strong interest in bribery, respondents see its prevention as strengthening administrative control.
When organizing anti-corruption measures, it is necessary to take into account the type of value-semantic attitude to grass-roots corruption in the form of bribery, which differentiates the views of adult working people about functions, consequences, factors, justification of bribery and its prevention.

\section{CONCLUSION}

The types of their value-semantic attitude to bribery as "Business economic transaction", "Instrumental value", "Illegal act" have been established among adult working subjects. Depending on the type of the attitude to bribery specific content of each of the cognitive, emotionalevaluative, and conative components of this attitude is revealed.

\section{REFERENCES}

[1] A.B. Kurdyumov, S.B. Gnezdilov, and V.V. Kiselev, "Corruption psychology in Turkey and Russia and prospects for the formation of anti-corruption behavior", Human capital. Russia. Vol: 2 (86), pp. 7-9, 2016.

[2] A. Gomis-Pomares, and L. Villanueva, "The effect of adverse childhood experiences on deviant and altruistic behavior during emerging adulthood". Psicothema. Spain. Vol: 32 (1), pp. 33-39, February, 2020. DOI: http://doi.org/ 10.7334/psicothema2019.142

[3] A.L. Juravlyov, and A.V. Yurevich, "Psychological factors of corruption", Psychological newspaper: We and the World. Russia. Vol: 2 (197), March, 2013. 
[4] A.L. Juravlyov, D.A. Kitova, and V.A. Sosnin, (Eds.) "Socio-psychological research of corruption". Moscow: Kogito-Center, 2017, p.285.

[5] A.M. Prozorov, "Problems of qualification of smallscale bribery". Bulletin of science and practice. Russia. Vol: 5(4), pp. 378-381, 2019. DOI: https://doi.org/10.33619/2414-2948/41/54

[6] A.S. Pestruilov, and L.V. Rudakov, "Corruption as a global anti-social phenomenon: history, psychological aspects of counteraction". World of science. Russia. Vol: 4 (3). p. 23, June, 2016.

[7] A. Zimelis, Corruption research: A need for an integrated approach. International Area Studies Review Vol: 23 num 3 (2020): 288-306.

[8] B.S. Vasyakin, N.A. Deberdeeva, and E.L. Pojarskaya, "Some psychological aspects of anticorruption", Achievements of modern science and education. Russia. Vol: 3 (2), pp. 61- 63, 2016.

[9] Criminal code of the Russian Federation No 63-FZ. June 13, 1996. Retrieved from: http://kremlin.ru/acts/bank/9555

[10] D. Abun, T. Magallanes, S. Lalaine, and M.J. Encarnacion, "Students' Attitude toward Corruption and their Behavioural Intention to Corrupt or not to Corrupt in the Future: The Philippines' Context", Journal of the Social Sciences. Kuvait. Vol: 23 (1), pp. 78-97, March 2020.

DOI: http://doi.org/10.13140/RG.2.2.33752.65285

[11] D.A. Kitova, "Psychological attitudes of modern youth to corruption", Scientific and practical journal "Humanization of education". Russia. V. 2, pp. 37-42, 2017.

[12] E.V. Chernishova, and V.O. Ermosh, "Sociopsychological understanding of corrupt behavior. Sustainable development of Russia: challenges, risks, strategies", Proceedings of the XIX international conference of the Humanities University.

Yekaterinburg, Publishing house of the Yekaterinburg University of Humanities, 2016. pp. 275-280.

[13] G. de Graaf, "Causes of corruption: towards a contextual theory of corruption". Public Administration Quarterly. United States. Vol: 31 (1), pp. 39-86, January, 2007.

[14] G. Harris and A.D. van der Merwe, "The scope for mobilising public opinion against corruption: the attitudes of Kwazulu-Natal university students", South
African Journal of Economic and Management Sciences. South Africa. Vol: 15 (3), pp. 282-293. January, 2012. DOI: http://doi.org/10.4102 / SAJEMS.V15I3.301

[15] I.B. Fan, "Political and psychological aspects of corruption reproduction". Scientific Yearbook of The Institute of philosophy and law of the Ural branch of the Russian Academy of Sciences. Russia. Vol: 14 (4), pp. 91-104, 2014.

[16] I.S. Havanova, "Research of the phenomenon of corruption in the framework of psychology", Personality, family and society: questions of pedagogy and psychology. Russia. Vol: 9-10 (55), pp. 82-87, 2015 .

[17] I. Kubbe, and A. Engelbert, "Corruption and the impact of democracy". Crime Law Social Change. Netherlands. V.70, pp. 175-178, November, 2017. DOI: http://doi.org/10.1007 / s10611-017-9732-0

[18] L. Velbovets, “Attitudes of Public Relations Professionals in Ukraine toward the Problem of Bribery”. (Accession No. 3262). 2012. Retrieved from: https://scholarsarchive.byu.edu/etd/3262

[19] M. Gorsira, L. Steg, A. Denkers, and W. Huisman, "Corruption in Organizations: Ethical Climate and Individual Motives". Administrative Sciences. United States. Vol: 8 (1), p. 4, February, 2018. DOI: https://doi.org/10.3390/admsci8010004

[20] M. Prasad, M.B.M. da Silva, and A. Nickow, "Approaches to Corruption: a Synthesis of the Scholarship", Studies in Comparative International Development. United States. Vol: 54 (1), pp. 96-132, March, 2019. DOI: http://doi.org/10.1007 / s12116-0189275-0

[21] M. Reshetnikov, "Psychology of corruption. Utopia and dystopia”. Saint Petersburg: Eastern European Institute of Psychoanalysis, 2008, p.101.

[22] M. Swaleheen, "Economic growth with endogenous corruption: an empirical study", Public Choice. Netherlands. V.146, pp. 23-41, January, 2011. DOI: https://doi.org/10.1007/ s11127-009-9581-1

[23] M.J.O. Barón, I.E. Bilbao, P.A. Urquijo, S.C. López, and A.P. Jimeno, "Moral emotions associated with prosocial and antisocial behavior in school-aged children", Psicothema. Spain. Vol: 30 (1), pp. 82-88, Февраль, 2018. DOI: http://doi.org/10.7334 / psicothema2016.143 
[24] M.N. Shafiq, “Aspects of Moral Change in India, 1990-2006: Evidence from Public Attitudes toward Tax Evasion and Bribery", World Development. United Kingdom. V.68, pp. 136-148, December, 2015. DOI: https://doi.org/10.1016/j.worlddev.2014.11.017

[25] O.V. Vannovskaya, "The problem of corruption in psychological phenomenology", Bulletin of Saint Petersburg University, Series 12. Russia. Vol: 3 (2), pp. 54-62, 2009.

[26] R. Fischer, M.C. Ferreira, T. Milfont, and R. Pilati, "Culture of Corruption? The Effects of Priming Corruption Images in a High Corruption Context", Journal of Cross-Cultural Psychology. United States. Vol: 45 (10), pp. 1594 -1605. October, 2014. DOI: http://doi.org/10.1177/0022022114548874

[27] R. Garifullin, "Psychological and psychotherapeutic approaches to the problem of bribery and bribery obsession (a new concept for solving the problem of corruption)", Investigator. Russia. Vol: 8 (184), pp.15-19, 2013.

[28] R.W. McGee, S. Benk, and D. Yüzbaşı, "Religion and Ethical Attitudes toward Accepting a Bribe: A Comparative Study”. Religions. Switzerland. Vol: 6 (4), p. 1165, September, 2015. DOI: http://doi.org/10.3390 / rel6041168

[29] S. Benk, B. Yüzba, and R.W. McGee, "Confidence in Government and Attitudes toward Bribery: A Country-Cluster Analysis of Demographic and Religiosity Perspectives", Religions. Switzerland. Vol: 8(1), p.8, February, 2017. DOI: http://doi.org/10.3390 / rel8010008

[30] S.M. Nikolayev, "The concept and essence of anticorruption education", Historical, philosophical, political and legal Sciences, cultural studies and art history. Issues of theory and practice. Russia. Vol: 7 (2). pp.159-162. 2011.

[31] S.T. Dzhaneryan, "Types of attitudes in students to bribery as the form of corruption", Social Sciences.

Pakistan. Vol: 11 (3), pp. 6475-6480, January, 2016.

[32] S.T.Dzhaneryan, D.I. Ggvozdeva, and I.N.

Astafyeva, "Understanding the causes for bribery by students with different types of attitudes to bribery", Social Sciences. Pakistan. Vol: 11 (3), pp. 6459-6464, January, 2016.

[33] S.T. Dzhaneryan, D.I. Gvozdeva, and E.A. Panina, "Types of attitudes to bribery among school and College students", Psychologist. Russia. V.4, pp. 65-81, August, 2017. DOI: http://doi.org/10.25136/2409. 8701.2017.4.23735

[34] S.T.Dzhaneryan, and D.I. Gvozdeva, "Types of value-semantic attitude to bribery among University students and working young people". Pedagogy and education. Russia. V.3, pp.1-11, August, 2018. DOI: http://doi.org/10.7256/2454-0676.2018.3.27223

[35] T. Hernandez, and R.W. McGee, "Attitudes toward bribery in Australia: a demographic study". Euro Asia Journal of Management. V. 24(1/2), pp. 57-91, December, 2014

[36] T. Jiang, J. Lindemans, and C. Bicchieri, "Can trust facilitate bribery? Experimental evidence from china, italy, japan, And the Netherlands", Social Cognition. United States. Vol: 33 (5), pp. 483-504, October, 2015. DOI: http://doi.org/10.1521 / soco.2015.33.5.483

[37] V.N. Myasishchev, "Psychology of relationships. Selected psychological works". Moscow: Wnstitute of practical psychology, Voronezh: NPO "MODEK", 1995 , p.356.

[38] V.V. Vasina, R.G. Khalitov, and I.M. Yusupov, "Possibility of changing perceptions of corruption in society", Current problems of Economics and Law. Russia. V.4, pp. 5-8, December, 2012.

[39] V.Yu. Golubovskiy, and T.N. Sinyukova, "Forms and types of corruption in modern Russian society". Political linguistics. Russia. Vol: 2 (52), pp. 240-245, 2015. 